\title{
VARIATION OF MORPHOMETRIC TRAITS WITHIN POPULATIONS OF GROUND BEETLES ANTHIA SEXMACULATA (COLEOPTERA: CARABIDAE) LOCATED IN DIFFERENT ECOGEOGRAPHICAL REGIONS IN EGYPT
}

By

\author{
MOSTAFA I. HASSAN ${ }^{1}$, DALIA A. ELSHEWY², AHMED S. BREAM ${ }^{1}$, \\ AND SABER A. RIAD ${ }^{1 *}$
}

Department of Zoology, Entomology Unit, Faculty of Science ${ }^{1}$, Al Azhar University, Nasr City, Cairo, and Department of Insect Classification and Survey ${ }^{2}$, Plant

Protection Research Institute, ARC, Dokki, Giza, Egypt. ( ${ }^{\star}$ Correspondence:saberiad60@azhar.edu.eg, Tel. 20201000262403)

\section{Abstract}

The morphometric measurements of populations of Anthia sexmaculata in different regions were studied in Egypt. A multivariate comparison of morphometric differences was undertaken by eyepiece micrometer on three different ecogeographical areas in Egypt; Western Mediterranean Coastal Desert (WMCD) (North Coast, Fouka and Mersa Matruh), Western Desert (Siwa, Bahariya and Dakhla Oases) and South Sinai (Saint Catherine and Taba Protected area and Sharm El Sheikh wadis). Twenty-one morphometric traits were studied. Traits best corresponding to the distinction of populations was distinguished by cluster and discriminant analysis (LDA). The first and second discriminant axes (Axis1 and Axis2) recorded 88.38\% and 11.62\%, respectively, of the total variation in studied sample. Multiple discriminant analysis revealed clear morphometric differences between West Mediterranean Costal Desert, Western Desert and South Sinai populations. Traits connected with morphometric measurements are good characters for differentiation between carabid beetles, South Sinai population of A. sexmaculatus have been shown to differ morphologically from the other populations in Egypt.

Key Words: Egypt, Biogeography, Morphometrics, Linear Discriminant Analysis, Anthia sexmaculata, Carabid beetle,

\section{Introduction}

Egypt occupies the northeastern part of the Africa. It is roughly quadrangular, extending about $1073 \mathrm{~km}$ from north to south and about $1229 \mathrm{~km}$ from east to west. Thus, the total area of Egypt is a little more than one million square kilometers $\left(1,019,600 \mathrm{~km}^{2}\right)$ occupying nearly $3 \%$ of the total area of Africa (Abu Al-Izz, 1971). The position of Egypt amongst the faunal regions of the world is a rather anomalous one, since it combines the characteristics of both Palaearctic and Afrotropical regions. It has generally been considered to belong to Palaearctic, but the Afrotropical element is much greater than usually thought (Steyskal and El Bialy, 1967). Egypt is a part of the Great Desert Belt and it is characterized by warm and almost rainless climate. Only the Coastal Strip, Gebel Elba and high mountains of southern Sinai receive comparatively higher rainfall. This is reflected on their floral and faunal composition (Larsen, 1991). Egypt is into 8 ecological zones; The Coastal Strip, Lower Nile Valley and Delta, Upper Nile Valley, El Faiyum Depression, Eastern Desert, Western Desert, Gebel Elba and Sinai (El Hawagry and Gilbert, 2014).

Within insect species, the size of each organ, appendage or body regions bears a specific relationship to overall body size (Shingleton et al, 2007). Positive correlations have been found between wings and body size, fore-femur length and body size, and body size and morphological traits associated with feeding mandibles, head (Stern and Emlen, 1999). These correlations, head width or mandible length are related to an ability to consume larger food items (Pearson and Stemberger, 1980). Such a positive relationship between feeding morphology and body size differed among populations because of dis- 
tinct resource availability or foraging strategies (Bommarco, 1998), and the food intake provided a major part of the resources used for reproduction (Juliano 1986).

Family Carabidae, the ground beetles, contains more than 40,000 described species classified into 86 tribes (Erwin, 1985). It is the largest adephagan family and one of the most speciose of beetle families. Suborder Adephaga is a relatively large group of specialized beetles morphologically defined by six abdominal ventrites, pygidial defense glands in adult and liquid-feeding mouthparts in larvae (Lawrence and Britton, 1991).

Although early studies on the morphological adaptations of carabids tried to relate especific characters with habitats, only a few adaptations to specific environments was detected as digging, tree-dwelling, or cave-dwelling species (Ribera et al, 1999). Morphological variability within group was associated with differences in habits, locomotion and feeding mechanism (Evans, 1990).

The morphometric measurements are used to clarify shape statistical analyses and to resolve phylogenies (Klingenberg and Marugan-Lobon, 2013), used in taxonomical revision (Grobler et al, 2006) and in integrative approach to systematics along with molecular data (Ober and Connolly, 2015).

An important question is which morphological traits should be analyzed? Redundancy leads to results disturbance. Morphometric measurements proved helpful in establishing phylogeny, species not easy to distinguish due to few or even no diagnostic traits (De Bivort et al, 2010; Navia et al, 2015).
The present study aimed to elucidate potential sub-specific differences of the different Egyptian populations of $A$. sexmaculata by using the cluster and discriminant analysis (LDA).

\section{Materials and Methods}

Study Area: Eleven localities of Egypt were included during a period of spring and summer months of year 2016 (Tab.1). Pitfall traps were used to collect $A$. sexmaculata populations of the studied localities. Each trap consisted of a rounded plastic jar with depth of $13 \mathrm{~cm}$ and an upper opening of $5.7 \mathrm{~cm}$ in diameter. Three different sites were selected in each locality to represent as much as possible of the local habitat heterogeneity. Twenty-five pitfall traps per each site with ten meters intervals were placed late afternoon at 16:00pm until the following sunrise. Trapping was conducted for two to three nights at each locality. The specimens were killed by ethyl acetate, processed and examined. Standard keys were adapted for taxonomic identification (Lobl and Smetana, 2008). The specimens were deposited at AlAzhar University Zoological Collection (AUZC), Faculty of Science, Al Azhar University. The geographical position and altitude of each site were recorded using a Garmin eTrex 30 GPS.

The study area was classified into three ecogeographical regions; Western Mediterranean Coastal Desert (North Coast, Fouka and Mersa Matruh), Western Desert (Siwa, Bahariya and Dakhla Oases) and South Sinai (Saint Catherine and Taba Protected area and Sharm El Sheikh wadis).

Table 1: Ecogeograplical regions, coordinates and collection of A. sexmaculata population samples

\begin{tabular}{|c|l|c|c|c|}
\hline \multirow{2}{*}{ No } & \multicolumn{1}{|c|}{ Locality } & \multicolumn{2}{c|}{ Co-ordinations } & \multirow{2}{*}{ Date } \\
\cline { 3 - 4 } & & Latitude & Longitude & \\
\hline 1 & Mersa Matruh, Matruh & $31.30902 \mathrm{~N}$ & $27.29444 \mathrm{E}$ & $5 / 2016$ \\
\hline 2 & Fouka, Matruh & $31.05086 \mathrm{~N}$ & $27.56188 \mathrm{E}$ & $5 / 2016$ \\
\hline 3 & Bagush, Matruh & $31.10422 \mathrm{~N}$ & $27.41474 \mathrm{E}$ & $4 / 2016$ \\
\hline 4 & El Zayton, Siwa Oasis & $29.15135 \mathrm{~N}$ & $25.79346 \mathrm{E}$ & $4 / 2016$ \\
\hline 5 & Siwa Oasis & $29.18073 \mathrm{~N}$ & $25.47638 \mathrm{E}$ & $4 / 2016$ \\
\hline 6 & Bahariya Oasis & $28.79477 \mathrm{~N}$ & $28.34275 \mathrm{E}$ & $7 / 2016$ \\
\hline 7 & Bahariya Oasis & $28.24414 \mathrm{~N}$ & $28.54131 \mathrm{E}$ & $7 / 2016$ \\
\hline 8 & Mute, Dakhla & $25.49454 \mathrm{~N}$ & $28.97892 \mathrm{E}$ & $7 / 2016$ \\
\hline 9 & Sharm El Sheikh, Sinai & $27.82994 \mathrm{~N}$ & $34.20170 \mathrm{E}$ & $4 / 2016$ \\
\hline 10 & Saint Katherine, Sinai & $27.84990 \mathrm{~N}$ & $34.22448 \mathrm{E}$ & $4 / 2016$ \\
\hline 11 & Taba Protectorate, Sinai & $28.89613 \mathrm{~N}$ & $34.92268 \mathrm{E}$ & $9 / 2016$ \\
\hline
\end{tabular}


Measurements: A total of 62 specimens were examined for morphometric analyses. Each specimen was measured by eyepiece micrometer; TL: total length, taken dorsally from head anterior border to elytron posterior border. AL: antenna length, total length of pedicel plus flagellum. HL: head length, taken dorsally from anterior border to posterior one after eyes. HW: maximum head width, taken dorsally. PL: maximum pronotum length, taken dorsally from anterior to posterior border at scutellum. PW: maximum pronotum width, taken perpendicular to pronotum length. EL: elytron length, distance between scutellum anterior border to elytron posterior border. EW: elytron maximum width. FF: forefemur length. FT: foretibia length. FTa foretarsus length. MF: mesofemur length, MT mesotibia length, MTa mesotarsus length, MeF: metafemur length, MeT metatibia length, MeTa metatarsus length.

Statistical Analysis: Discriminant analysis (LDA) was done by using (Past3) software program. Data was analyzed using statistical package for social sciences (SPSS) computer software package, version 20 for One-way ANOVA (Levesque, 2007).

\section{Results}

A comparison of A. sexmaculata populations collected from three different ecogeographical regions (Tab. 2) based on 17 absolute morphometric characters and 4 ratios was undertaken (Tab. 3).
The specimens of Sinai showed the highest for 6 absolute values and two ratios and that of Mediterranean Coastal Desert (WMCD) recorded highest of three absolute values. As

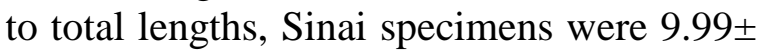
$0.11 \mathrm{~mm}$, total lengths of WMCD specimens was $9.86 \pm 0.07 \mathrm{~mm}$, which was significant.

Highest mean lengths of the antenna, forefemur, metatibia, metatarsus and the values of (pronotum and elytron) width and ratios of pronotum width/pronotum length and elytron length/pronotum length were recorded for Sinai population. Highest mean values of forefemur length, mesofemur length and metafemur length were recorded for WMCD population (Tab. 3).

Discriminant Analysis (LDA): Discriminant analysis based on 21 variables showed significant, intergroup variables was carried out. The analysis generated two principle components for all samples. The first and second discriminant axes (Axis1 and Axis2) recorded $88.38 \%$ and $11.62 \%$, respectively, of the total variation in samples (Tab. 4), and actor loading values for each measurement was given (Tab. 5).

By comparing all morphological characters, cluster analysis showed that the three sampled populations of $A$. sexmaculatus are clustered in two discrete groups. First cluster consisted of the populations of the Western Desert and WMCD. Second cluster contained South Sinai population only.

Table 2: Ecogeograplical regions, specimens No. \& Museum No. of A. sexmaculata collected during spring and summer 2016

\begin{tabular}{|l|c|c|}
\hline Locality & No. of specimens & Museum number \\
\hline Saint Katherine, Sinai & 7 & IC01745 - IC01752 \\
\hline Sharm El Sheikh, Sinai & 4 & IC01753 - IC01756 \\
\hline Taba Protectorate, Sinai & 3 & IC01757 - IC01759 \\
\hline Bagush, Matruh & 11 & IC01760 - IC01770 \\
\hline Mersa Matruh, Matruh & 2 & IC01771 - IC01772 \\
\hline Fouka, Matruh & 6 & IC01773 - IC01778 \\
\hline \multirow{2}{*}{ Bahariya Oasis } & 7 & IC01779 - IC01785 \\
\cline { 2 - 3 } Mute, Dakhla & 2 & IC01786 - IC01787 \\
\hline El Zayton, Siwa Oasis & 3 & IC01788 - IC01790 \\
\hline Siwa Oasis & 7 & IC01791 - IC01800 \\
\hline
\end{tabular}


Table 3: Morphological measurements ( $\mathrm{mm}$ ) for A. sexmaculatus specimens from three Egyptian ecogeographical areas. m.

\begin{tabular}{|c|c|c|c|c|}
\hline Character & WMCD & Western Desert & Sinai & F value \\
\hline $\mathrm{TL}$ & $46.14 \pm 0.09(46.00-46.30) 17$ & $46.12 \pm 0.12(46.00-46.30) 34$ & $46.16 \pm 0.12(46.00-46.30) 12$ & .662 \\
\hline $\mathrm{AL}$ & $21.11 \pm 0.08(21.00-21.20) 17$ & $21.14 \pm 0.05(21.10-21.20) 34$ & $21.16 \pm 0.05(21.10-21.20) 12$ & 2.327 \\
\hline HL & $11.18 * \pm 0.08(11.10-11.30) 17$ & $11.06 * \pm 0.08(11.00-11.20) 34$ & $11.18 * \pm 0.09(11.10-11.30) 12$ & 18.654 \\
\hline HW & $9.16 * \pm 0.07(9.10-9.30) 17$ & $9.24 * \pm 0.05(9.20-9.30) 34$ & $9.14 * \pm 0.05(9.10-9.20) 12$ & 17.800 \\
\hline PL & $10.09 \pm 0.08(10.00-10.20) 17$ & $10.14 \pm 0.08(10.00-10.20) 34$ & $10.12 \pm 0.08(10.00-10.20) 12$ & 1.662 \\
\hline PW & $9.86^{*} \pm 0.07(9.80-10.00) 17$ & $9.86 * \pm 0.05(9.80-9.90) 34$ & $9.99 * \pm 0.11(9.90-10.20) 12$ & 16.812 \\
\hline EL & $24.71 \pm 0.08(24.60-24.80) 17$ & $24.76 \pm 0.05(24.70-24.90) 34$ & $24.76 \pm 0.05(24.70-24.90) 12$ & 3.921 \\
\hline EW & $14.78 \pm 0.08(14.70-14.90) 17$ & $14.76 \pm 0.08(14.70-14.90) 34$ & $14.78 \pm 0.09(14.70-14.90) 12$ & .838 \\
\hline $\mathrm{FF}$ & $10.16 \pm 0.09(10.00-10.30) 17$ & $10.20 \pm 0.09(10.10-10.30) 34$ & $10.27 \pm 0.09(10.20-10.40) 12$ & 4.933 \\
\hline FT & $7.82 \pm 0.07(7.70-7.90) 17$ & $7.86 \pm 0.05(7.80-7.90) 34$ & $7.86 \pm 0.05(7.80-7.90) 12$ & 2.529 \\
\hline Fta & $7.10 \pm 0.07(7.00-7.20) 17$ & $7.08 \pm 0.08(7.00-7.20) 34$ & $7.09 \pm 0.08(7.00-7.20) 12$ & .323 \\
\hline MF & $12.22 \pm 0.07(12.10-12.30) 17$ & $12.20 \pm 0.06(12.10-12.30) 34$ & $12.20 \pm 0.06(12.10-12.30) 12$ & .716 \\
\hline MT & $9.02 \pm 0.07(8.90-9.10) 17$ & $9.00 \pm 0.09(8.90-9.10) 34$ & $9.02 \pm 0.08(8.90-9.10) 12$ & .444 \\
\hline Mta & $10.18 \pm 0.08(1.10-10.30) 17$ & $10.16 \pm 0.08(1.10-10.30) 34$ & $10.18 \pm 0.09(1.10-10.30) 12$ & .838 \\
\hline $\mathrm{MeF}$ & $15.34 * \pm 0.05(15.30-15.40) 17$ & $15.24 * \pm 0.05(15.20-15.30) 34$ & $15.33 * \pm 0.05(15.30-15.40) 12$ & 27.654 \\
\hline $\mathrm{MeT}$ & $13.22 * \pm 0.08(13.10-13.30) 17$ & $13.18 * \pm 0.04(13.10-13.30) 34$ & $13.27 * \pm 0.05(13.20-13.30) 12$ & 11.312 \\
\hline MeTa & $10.89 \pm 0.08(10.80-11.00) 17$ & $10.92 \pm 0.08(10.80-11.00) 34$ & $10.93 \pm 0.08(10.80-11.00) 12$ & 1.087 \\
\hline HW/HL & $0.82 * \pm 0.01(0.81-0.84) 17$ & $0.84 * \pm 0.01(0.83-0.85) 34$ & $0.82 * \pm 0.01(0.81-0.83) 12$ & 39.324 \\
\hline $\mathrm{PW} / \mathrm{PL}$ & $0.98 * \pm 0.01(0.96-0.99) 17$ & $0.97 * \pm 0.01(0.96-0.98) 34$ & $0.99 * \pm 0.01(0.97-1.01) 12$ & 12.790 \\
\hline EW/EL & $0.60 \pm 0.00(0.59-0.60) 17$ & $0.60 \pm 0.00(0.59-0.60) 34$ & $0.60 \pm 0.00(0.59-0.60) 12$ & .441 \\
\hline EL/PL & $2.45 \pm 0.02(2.42-2.48) 17$ & $2.44 \pm 0.02(2.42-2.48) 34$ & $2.45 \pm 0.02(2.42-2.48) 12$ & .644 \\
\hline
\end{tabular}

Data shown as mean \pm SD (range) number of specimens, $\left(\mathrm{P}<0.05^{*}=\right.$ significant), TL: total length, AL: antenna length, HL: head length, HW: head width, PL: pronotum length, PW: pronotum width, EL: elytron length, EW: elytron width, FF: forefemur length, FT: foretibia length, FTa: foretarsus length, MF: mesofemur length, MT: mesotibia length, MTa: mesotarsus length, MeF: metafemur length, MeT: metatibia length, MeTa: metatarsus length, HW/HL: head width/head length, PW/PL: pronotum width/pronotum length, EW/EL: elytron width/elytron length and El/PL: elytron length/pronotum length.

Table 4: Discriminant analysis based on 21 morphologic variables

\begin{tabular}{|c|c|c|}
\hline & Eigen value & \% explained \\
\hline Axis1 & 18.898 & 88.38 \\
\hline Axis2 & 2.4969 & 11.62 \\
\hline
\end{tabular}

Table 5: Factor loading values for each morphological character

\begin{tabular}{|c|c|c|}
\hline Trait & Axis 1 & Axis 2 \\
\hline TL & 0.00022581 & 0.0071749 \\
\hline AL & 0.0036568 & 0.0014405 \\
\hline HL & 0.002211 & 0.014684 \\
\hline HW & -0.0064744 & -0.024083 \\
\hline PL & 0.0011958 & -0.0063013 \\
\hline PW & 0.011725 & 0.0059638 \\
\hline EL & 0.002045 & -0.0095374 \\
\hline EW & 0.002211 & 0.014684 \\
\hline FF & 0.0037096 & -0.0080363 \\
\hline FT & 0.0029772 & -0.006106 \\
\hline Fta & -0.00062299 & 0.0024134 \\
\hline MF & 0.00038066 & 0.0027991 \\
\hline MT & -0.0010818 & 0.003706 \\
\hline Mta & 0.002211 & 0.014684 \\
\hline MeF & 0.0030597 & 0.026962 \\
\hline MeT & 0.0035501 & -0.009994 \\
\hline MeTa & 0.0050076 & 0.0017879 \\
\hline HW/HL & -0.00085549 & -0.0033452 \\
\hline PW/PL & 0.001053 & 0.0012265 \\
\hline EW/EL & -0.00011771 & 0.00018463 \\
\hline EL/PL & $-8.935 E-05$ & 0.00087663 \\
\hline
\end{tabular}

\section{Discussion}

The importance of examining variation of morphological traits was recently re-emphasised because these traits are (i) used extensively for taxonomy, (ii) partially under gen- etic control, (iii) target of selection, and (iv) reflect intraspecific clinal divergence (Garnier et al, 2005). Also, variation in morphology can exhibit clear patterns of differentiation that molecular markers may not detect 
(Nice and Shapiro 1999). When comparing geographically separated populations by means of a morphometric data set can exert some influence on the observed differences (Mamuris et al, 1998). The present study attempted to minimize additional variances through size standardization, data transformation by performing separate discriminant analysis.

Extensive variation in morphometric variables were existed between the studied populations. In addition, within the Western Desert (Bahariya Oasis, Siwa Oasis and Dakhla Oiasis) studied populations were observed to be most similar. The West Mediterranean Costal Desert (North Coast, Fouka and Mersa-Matruh) were also most similar, whilst the South Sinai (Saint Catherine and Taba Protected area and Sharm El Sheikh wadis) populations were also most similar, but dissimilar with Western Desert and WMCD populations. This is supported not only by the cluster analysis but also by discriminant analysis.

The variables of primary importance in separating the South Sinai population was related to the larger size of $A$. sexmaculatus specimens when compared with other populations. However, the relatively high discriminant of the Western Deserts, West Mediterranean Costal Desert and South Sinai populations variables, may represent subspeciation of $A$. sexmaculatus. These three ecogeographical areas are separated from each other by huge geographical barriers which prevent transformation of the studied species between them in addition to the limited home range of this species, these results are agreement with (Hassan et al, 2017), they studied the different ecogeographical populations of beetle's species in Egypt.

The Nile River and its narrow floodplain and Suez Canal act as a barrier for desert faunal dispersion separating the Western Deserts and Sinai. In early geological time, lakes and wetlands of the Ismuth of Suez (which is now traversed by Suez Canal) expanded greatly and extensive marshland conditions developed closing this gate to Africa. The Gulf of Suez, with its shallow profile, appears to have remained an exposed basin throughout most of the Pleistocene, and until about 14,000-15,000 years ago, when sea levels rose above about $50 \mathrm{~m}$, linking Sinai Peninsula to the Eastern Desert (Derricourt, 2005; Bailey et al, 2007). Derricourt (2005) suggested that during drier periods of the Pleistocene, the Suez Gulf was reduced and Sinai Peninsula was readily accessible from the Eastern Desert with two regions forming one, largely continuous arid zone. This is may be the reason for similarity between South Sinai and Eastern, Western Deserts A. sexmaculatus populations.

During drastic climate changes, many species and populations can survive only in areas with more stable climate, called refugia. Throughout Quaternary, there were many such places in Egypt and surrounding areas. It is quite possible that processes of differentiation and speciation in genus Anthia were heavily influenced by contractions and subsequent expansions of ranges of populations due to climate change. For example, two populations of one species may have been isolated in two different refugia which may lead to allopatric speciation. Isolation in mountainous refugia can lead to patterns in morphological diversity which are in many aspects consistent with phylogeny (Ober and Connolly, 2015). However, all distinguished Anthia species have similar ecological niches, which may result in similar adaptations to environment. That is why the possibility that many aspects of morphology do not reflect phylogeny but simply adaptation to the common environment, must be considered.

Spatial and temporal expansion and contraction of desert conditions in the Sahara appear to have acted as an important driver of faunal diversification and speciation events. Palaeoclimatic cycles continually adjusted the boundaries between the desert, other environments and their associated biodiversity (Dumont, 1982; Le Houerou, 1992; 1997; Drake et al, 2011). Vicariance events asso- 
ciated with Saharan aridity episodes become the main diversification force for post Pleistocene allopatry (Douady et al, 2003; Nyari et al, 2010). Such events are believed to result in allopatric isolation, which in turn induced the interruption of gene flow and evolution of independent lineages or new species.

The response of a given animal taxon to Saharan vicariant events varied according to taxon's habitat requirements. During humid periods, desert-adapted animals become restricted to remaining desert habitat fragments, or the remaining arid core of the Sahara. In their isolation, they were likely to underwent morphologic and genetic allopatric diversification (Boratynski et al, 2012). During a subsequent arid episode, isolated populations of desert-adapted species will expand their ranges, possibly merging the different meta-populations into larger populations. If the previous allopatric divergence was not sufficient to give reproductive isolation, genetic mixing took place and a uniform population with a free gene flow would result. Desert oases depressions play a key role in diversification patterns across the Sahara by acting as ecological refugia for many species and facilitating gene flow during favorable climatic conditions (Hassan et al, 2017).

\section{Conclusion}

The traits connected with morphometric measurements mentioned above proved to be good characters to differentiate between the carabid beetles.

South Sinai $A$. sexmaculatus population showed different morphological characters from the other populations in Egypt, as being the most distinct than one.

\section{Acknowledgments}

The authors would like to express their deep gratitude to Prof. Dr. Mostafa A. Saleh and Mr. Ahmed B. Sayed, Department of Zoology, Faculty of Science, Al Azhar University, for their kind help in collecting most of these specimens and for their helpful advice.

\section{References}

Abu Al-lzz, MS, 1971: Landforms of Egypt: Translated by Dr. Yusuf A. Fayid; The American University, Cairo Press, Cairo, Egypt.

Bailey, GN, Flemming, NC, King, GC, Lambeck, K, et al, 2007: Coastlines, submerged landscapes and human evolution: The Red Sea Basin and the Farasan Islands. J. Coast. Arch. 2, 2:12760.

Bommarco, R, 1998: Reproduction and energy reserves of a predatory carabid beetle relative to agroecosystem complexity. J. Ecol. Appl. 8:84653.

Boratynski, Z, Brito, JC, Mappes, AT, 2012: The origin of two cryptic species of African desert jerboas (Dipodidae: Jaculus). Biol. J. Linn. Soc. 105:435-45.

De Bivort, BL, Clouse, RM, Giribet, G, 2010: A morphometrics-based phylogeny of the temperate Gondwanan mite harvestmen (Opiliones, Cyphophthalmi, Pettalidae). J. Zool. Syst. Evol. Res. 48:294-309.

Derricourt, R, 2005: Getting "Out of Africa": Sea crossings, land crossings and culture in the hominin migrations. J. Prehist. 19, 2:119-32.

Douady, CJ, Catzeflis, F, Raman, J, Springer, MS, Stanhope, MJ, 2003: The Sahara as a vicariant agent, and the role of Miocene climatic events, in the diversification of the mammalian order Macroscelidea (elephant shrews). Proceed. the Nat. Acad. Sci. 100, 14:8325-30.

Drake, NA, Blench, R, Armitagec, S, Bristol, C, White, K 2011: Ancient watercourses and biogeography of the Sahara explain the peopling of the desert. Proceed. Nat. Acad. Sci. 108, 2: 458-62.

Dumont, HJ, 1982: Relict distribution patterns of aquatic animals: Another tool in evaluating late Pleistocene climate changes in the Sahara and Sahel. Palaeoecology of Africa and the Surrounding Islands, 14, 1-24.

El Hawagry, M, Gilbert, F, 2014: Zoogeographical affinities and faunal relationships of the bee flies (Diptera: Bombyliidae) in Egypt. Zool. Mid. 60:50-6.

Erwin, TL, 1985: The Taxon Pulse: A general pattern of lineage radiation and extinction among carabid beetles. In: Ball GE (ed.), Taxonomy, Phylogeny and Zoogeography of Beetles and Ants Junk, The Hague.

Evans, ME, 1990: Habits or habitats: Do carabid of locomotor adaptations reject habitats or life styles? J. Ecol. Environ. 67:295-305. 
Garnier, S, Magniez-Janin, F, Rasplus, JY, Alibert, P, 2005: When morphometry meets genetics: inferring the phylogeography of Carabus solieri using Fourier analyses of pronotum and male genitalia. J. Evol. Biol. 18:269-80.

Grobler, GC, van Rensburg, LJ, Bastos, DS, Chimimba, CT, Chown, SL, 2006: Molecular and morphometric assessment of the taxonomic status of Ectemnorhinus weevil species (Coleoptera: Curculionidae, Entiminae) from the subAntarctic Prince Edward Islands. J. Zool. Syst. Evol. Res. 44: 200-11.

Hassan, MI, Bream, AS, Younes, MI, EIShewy, DA, Riad, SA, 2017: Morphometric comparison Between Western, Eastern Deserts and Sinai populations of Mesostena angustata (Coleoptera: Tenebrionidae) in Egypt. Egypt J. Zool. 67:51-66.

Juliano, SA, 1986: Food limitation of reproduction and survival for population of Brachinus (Coleoptera: Carabidae). J. Ecol. 67: 1036-45.

Klingenberg, CP, Marugan-Lobon, J, 2013: Evolutionary covariation in geometric morphometric data: Analyzing integration, modularity, and allometry in a phylogenetic context. Syst. Biol. 62: 591-610.

Larsen, TB, 1991: The Butterflies of Egypt. Svendborg: Apollo Books. ISBN 87-88757-145, 240.00 DKr.

Lawrence, IF, Britton, EB, 1991: The Insects of Australia. $2^{\text {nd }}$ ed. Melbourne Univ. Press, Melbourne.

Le Houerou, HN, 1992: Outline of the biological history of the Sahara. J. Environ. 22:3-30.

Le Houerou, HN, 1997: Climate, flora and fauna changes in the Sahara over the past 500 million year. J. Env. 37: 619-47.

Levesque, R, 2007: Programming and Data Management for SPSS Statistics 19.0: A Guide for SPSS Statistics and SAS Users. SPSS, Chicago.

Lobl, I, Smetana, A, 2008: Catalogue of Palaearctic Coleopteran. Vol. 5, Tenebrionoidea. Apollo Books, ISBN: 87-88757-84-6. EUR 123.00/ DKK 860.00.
Mamuris, Z, Apostolidis, AP, Panagiotaki, P, Theodorou AJ, Triantaphyllidis, CL, 1998: Morphological variation between red mullet populations in Greece. J. Biol. 52:107-17.

Navia, D, Ferreira, CB, Reis, AC, Gondim, M G, 2015: Traditional and geometric morphometrics supporting the differentiation of two new Retracrus (Phytoptidae) species associated with heliconias. Exp. Appl. Acarol. 67:87-121.

Nice, CC, Shapiro, AM, 1999: Molecular and morphological divergence in the butterfly genus Lycaeides (Leipdoptera: Lycaenidae) in North America: evidence of recent speciation. J. Evol. Biol. 12:936-50

Nyari, AS, Peterson, TA, Rathbun, GB, 2010: Late Pleistocene potential distribution of the North African sengi or elephant-shrew Elephantulus rozeti (Mammalia: Macroscelidea). Afri. Zool. 45, 2:330-9.

Ober, K, Connolly, CT, 2015: Geometric morphometric and phylogenetic analyses of Arizona Sky Island populations of Scaphinotus petersi Roeschke (Coleoptera: Carabidae). J. Zool. Linn. Soc. 175:107-18.

Pearson, DL, Stemberger, SL, 1980: Competition, body size and the relative energy balance of adult tiger beetles (Coleoptera: Cicindelidae). Amer. Mid. Nat. J. 104:373-7.

Ribera, I, and Nilsson, AN, 1995: Morphometric patterns among diving beetles (Coleoptera: Noteridae, Hygrobiidae, Dytiscidae). Canad. J. Zool. 73:2343-60.

Shingleton, AW, Frankino, WA, Flatt, T, Nijhout, HF, Emlen, DJ, 2007: Size and shape: the developmental regulation of static allometry in insects. Bio-essays 29:536-48.

Stern, DL, Emlen, DJ, 1999: The developmental basis for allometry in insects. J. Devel. Ecol. 126:1091-101.

Steyskal, GC, El-Bialy, S 1967: A list of Egyptian Diptera with a Bibliography and Keys to Families. The Egyptian Ministry of Agriculture Tech. Bull. 3:12-8.

Fig. 1: Collection sites in different ecogeographical regions in Egypt

Fig. 2: A dendrogram showing similarity between three A. sexmaculatus populations of Western Mediterranean Coastal Desert (WMCD), Western Desert and Sinai based on 17 morphological measurements and 4 ratios. Fig. 3: Discriminant analysis of morphological measurements of three A. sexmaculatus populations.

According to discriminant analysis, Figure (3) showed that specimens from Western Desert populations (Bahariya Oasis and Siwa Oasis) and Western Mediterranean Costal Desert Specimens are somewhat similar. South Sinai population appeared as a distinct group different from all other populations. According to both the cluster and discriminant analysis statistical analysis showed that the populations of A. sexmaculatus from South Sinai has a higher phenetic distance from other populations 


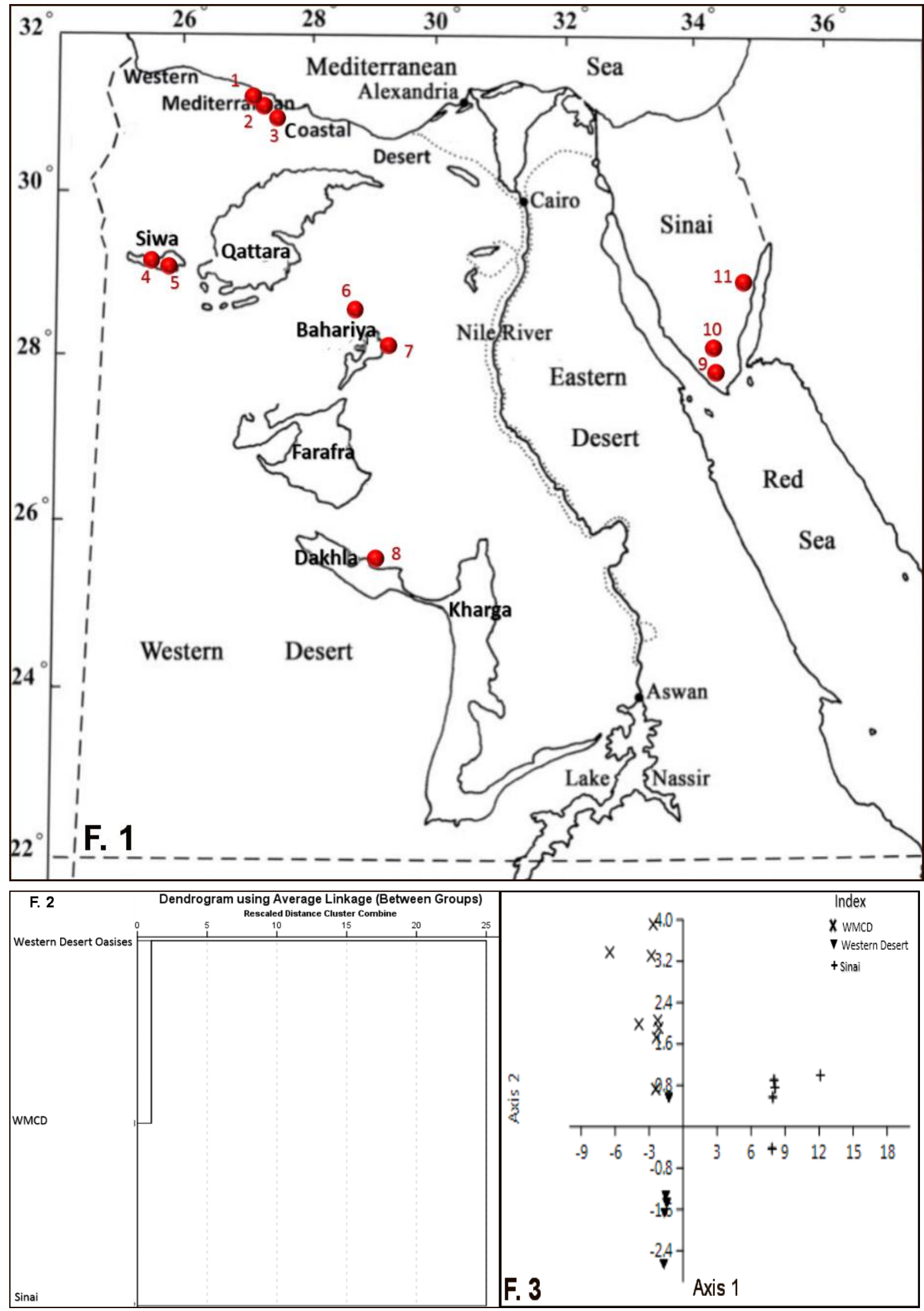

